Abstracta Iranica Abstracta Iranica

Revue bibliographique pour le domaine irano-aryen

Volume 31 | 2011

Comptes rendus des publications de 2008

\title{
The Raging Torrent. Historical Inscriptions from Assyria and Babylonia Relating to Ancient Israel. Jerusalem, 2008, 250 p.
}

\section{Astrid Nunn}

\section{OpenEdition}

1 Journals

\section{Édition électronique}

URL : http://journals.openedition.org/abstractairanica/39167

DOI : 10.4000/abstractairanica.39167

ISSN : 1961-960X

Éditeur :

CNRS (UMR 7528 Mondes iraniens et indiens), Éditions de l'IFRI

\section{Édition imprimée}

Date de publication : 15 mai 2011

ISSN : 0240-8910

Référence électronique

Astrid Nunn, « The Raging Torrent. Historical Inscriptions from Assyria and Babylonia Relating to Ancient Israel. Jerusalem, 2008, 250 p. », Abstracta Iranica [En ligne], Volume 31 | 2011, document 38, mis en ligne le 15 février 2012, consulté le 05 octobre 2020. URL : http://journals.openedition.org/ abstractairanica/39167 ; DOI : https://doi.org/10.4000/abstractairanica.39167

Ce document a été généré automatiquement le 5 octobre 2020.

Tous droits réservés 


\title{
The Raging Torrent. Historical Inscriptions from Assyria and Babylonia Relating to Ancient Israel. Jerusalem, 2008, 250 p.
}

\author{
Astrid Nunn
}

1 Les « Chroniques Babyloniennes » racontant la prise de Babylone par Cyrus II comptent parmi les textes assyriens et babyloniens qui mentionnent des paysages ou des villes situés aujourd'hui en Palestine et en Jordanie. Le document-clef est évidemment le «cylindre de Cyrus» (p. 224-230), connu aujourd'hui avant tout pour être l'édit de Cyrus permettant aux Juifs exilés à Babylone de retourner à Jérusalem. L'A. présente le contenu historique et géographique de ces deux textes sous l'optique de l'ouest avec une bibliographie en conséquence.

\section{INDEX}

Thèmes : 3.2.2. Pré-Achéménides et Achéménides

\section{AUTEURS}

\section{ASTRID NUNN}

Université de Munich 